\title{
Investigation of Mitodepressive and Clastogenic Potentials of Diatomaceous Earth Based on Plant Bioassay
}

\author{
Shaimaa Selmi Sobieh \\ Botany Department, Faculty of Women for Arts, Science and Education, Ain Shams \\ University, Cairo, Egypt.
}

\begin{abstract}
THE PRESENT study evaluated the mitodepressive and clastogenic effects of different concentrations of Mozambique diatomaceous earth (DE) on Vicia faba L. root meristems. The effects of different DE concentrations (10,30 and 60\%) for 3, 6 and $12 \mathrm{~h}$ have been studied on mitotic process, micronucleus frequency, pollen sterility, some biochemical parameters and ultrastructure of internal organelles. Significant dose and time dependent suppression of MI was observed. Various types of mitotic aberrations were observed in all treatments and spindle disturbance was the most common type induced. The genotoxic effect of DE was monitored by the induction of high ratio of micronucleus and reduction in pollen fertility. As well, DE suspensions caused drastic damages on cellular organelles in dose and time dependent manner. Gene expression was changed as DNA and protein synthesis was inhibited. All present results revealed the predominance clastogenic and genotoxic effect of DE suspension on Vicia faba $\mathrm{L}$, which were concentration and time dependant.
\end{abstract}

Keywords: Mozambique diatomaceous earth (DE), Mitotic arrest, Genotoxic effect, DNA \& protein synthesis depression, Ultrastructural aberrations, Vicia faba L.

\section{Introduction}

Diatomaceous earth (DE) is a naturally occurring soft, siliceous sedimentary rock that is easily crumbled into a fine white to off-white powder. $\mathrm{DE}$ is harvested from sediments at the bottom of oceans, lakes and rivers around the globe. It comes from single-celled diatoms algae with microscopic, geometric shells made of silicon dioxide. Over millennia, diatoms accumulate in aquatic sediments as fossils that can be harvested and dried into a fine dust. It has a particle size ranging from less than $3 \mu \mathrm{m}$ to more than $1 \mathrm{~mm}$, but the most common size ranging from 10 to $200 \mu \mathrm{m}$. Besides, amorphous silica (from about 60 to about $93 \%$ ), there are numerous other elements such as aluminium, magnesium, calcium, sodium, iron, phosphorus, sulphur, nickel, zinc, manganese and others (Subramanyam \& Roesli, 2000).

DEs are used in various industrial products such as detergents, as a mild abrasive, a drillingmud additive. Moreover, DE has been used in skin products, in filtration systems for swimming pools, a source of mineral additive in pet food (Snetsinger, 1988) and is extremely used in insect control (Faulde, et al., 2006 and Hosseini et al., 2014). Korunic (1998) reported that DE dusts have abrasive and physico-sorptive properties therefore; DE dusts have strong effect against stored-product insects. The fine powder of DE has the ability to absorb lipids from the waxy outer layer of insect's, causing dehydration of the insects. Kavallieratos et al. (2005) and Chanbang et al. (2007) reported that several DE formulations effective against storedgrain pests are now present in commercial forms.

Subramanyam et al. (1994) reported that, $\mathrm{DE}$ has low mammalian toxicity (DE rat oral $\mathrm{LD}_{50}>5,000 \mathrm{mg} \mathrm{kg}^{-1}$ of body weight), but the side effects of DE caused due to the accumulation of $\mathrm{DE}$ residues in stored grains and their adverse environmental impact must be taken in consideration. DE can contain crystalline silica (from 0.1 to $50 \%$ ) depending on the source and processing. In year 1997 The International Agency for Research on Cancer (IARC) has reported that crystalline silica has the capability to form cancer in human cells (IARC, 1997) by generating reactive oxygen species (ROS), while, no classification for the carcinogenicity potency of amorphous (DEs) was informed may be due to the limitation of available epidemiological and experimental data. Some amorphous DE products are biologically active like crystalline silicas of mineral origin. Essential characteristics of DE are determined

Corresponding author email: shimaa.sobieh@women.asu.edu.eg Telephone:+20201024314943

DOI: 10.21608/ejbo.2018.3754.1176

Edited by: Prof. Dr. Abdelfattah Badr, Faculty of Science, Helwan University, Cairo, Egypt.

(C)2019 National Information and Documentation Center (NIDOC) 
by the origin of it, structure of surface and some external factors such contaminants and/or pretreatments. All these characteristics can affect the biological activity of DE (IARC, 1997).

Previous study by Freo et al. (2014) proved that, the application of increasing doses of diatomaceous earth changes the physical and chemical characteristics of wheat grains stored, with consequent reduction of the flour technological quality. Besides, Fubini et al. (2001) and Elias et al. (2002) showed that DEs were cytotoxic and induced morphological transformation of Syrian hamster embryo (SHE) cells, which further acquired tumorigenic properties. Nattrass et al. (2015) characterised the physicochemical properties and toxic potential of a range of globally sourced DE samples, and revealed that the toxic potential of DE varies by processing technique and source.

Most previous in vivo and in vitro studies on genotoxic effects showed only few data on the effects of DEs, therefore the present study has started up systematic explorations on different doses of Mozambique DE suspension for different time of exposure to show up the cytological effects elicited on plant cells (Vicia faba) due to the accumulation of DE's residues in treated plants. The present paper reports data on the cytotoxicity and biochemical alterations induced in Vicia faba root cells caused by different doses of Mozambique DE suspension.

\section{Materials and Methods}

Preparation of diatomaceous earth (DE) suspension Diatomaceous earth (DE) used in the present study is a naturally occurring sedimentary rock in Mozambique. Different weights of DE powder $(10,30$ and $60 \mathrm{~g})$ were dissolved in $100 \mathrm{ml}$ of distilled water to obtain suspension solutions with concentrations of 10,30 and $60 \%$. These concentrations were chosen after preliminary studies using different concentrations. The concentrations below $10 \%$ had no effect, while the concentrations above $60 \%$ were highly toxic on Vicia faba root

\section{The $\mathrm{pH}$ value of solutions}

The $\mathrm{pH}$ value of each concentration was measured using Hanna (pH210) instrument.

\section{Plant bioassay}

The broad beans seeds (Vicia faba L., $2 \mathrm{n}=$
12, var. Giza 843) were obtained from The Crop Research Institute, Agriculture Research Center Giza, Egypt. The seeds were washed several times with distilled water and once with $\mathrm{HgCl}_{2}$ then once again with distilled water. Seeds of Vicia faba were soaked for $24 \mathrm{~h}$ in distilled water then transferred to petri-dishes containing moist cotton bed (five replicates, 10seeds/replicate of equal size and weight about $100 \mathrm{gm}$ ), when the germinated roots reached about $3 \mathrm{~cm}$ in length (after 5 days) were treated with each concentration of DE suspension for 3,6 and $12 \mathrm{~h}$ and distilled water for the control to be subjected to the following assays.

\section{Cytogenetic analysis}

Mitotic activity analysis

Fifty germinated seeds were soaked on each concentration (10, 30 and $60 \%$ ) of DE suspension and distilled water for the control for 3, 6 and $12 \mathrm{~h}$. Root meristems, were fixed in Carnoy's fixative (glacial acetic acid/ethanol $1: 3$ ) at $4^{\circ} \mathrm{C}$ for $24 \mathrm{~h}$, hydrolyzed in $1 \mathrm{~N} \mathrm{HCl}$ at $58-60^{\circ} \mathrm{C}$ for $10 \mathrm{~min}$ then stained with Schiff's reagent. Squashed specimens were analyzed at $400 \mathrm{x}$ magnification using Olympus Microscope (BX50). The most frequent abnormalities were pictured using Panasonic digital camera CP230. Mitotic index (MI) was expressed as the number of dividing cells per 1000scored cells. The proportion of mitotic phases and percentage of mitotic anomalies were calculated in the dividing cells of root tip.

\section{Determination of micronucleus (genotoxicity test)}

Micronucleus test was performed according to Ma et al. (1995). For scoring micronucleus (MN) frequency, cells with micronucleus were counted among 5000cells from five $V$. faba root tips of each treatment and control (1000cells for each root tip). Micronuclei which localized inside the cell wall and in the cytoplasmic area beside the main nucleus were counted.

\section{Determination of pollen sterility}

$V$. faba seeds treated with different DE suspension doses were cultured in the experimental pots. The anthers from fresh mature buds were soaked in aqueous solution of potassium iodide (KI). Viable pollen grains (with blue stained nuclei) and the sterile pollen grains (with no stain) were counted at 400x magnification using Olympus Microscope (BX50) the percentage of pollen sterility was calculated using the formula: 
Pollen sterility $\%=$ Number of sterile pollen grains/ Total number of pollen grains X100

\section{Biochemical analysis \\ Determination of protein content}

Protein content in treated and untreated $V$. faba roots was estimated using $0.5 \mathrm{~g}$ of fresh tissue. The root tissues were air dried, frozen in liquid $\mathrm{N}_{2}$ and ground to a fine powder. Powdered tissues were extracted by $1 \mathrm{ml} 80 \%$ ethyl alcohol, precipitated for $15 \mathrm{~min}$ at $4000 \mathrm{rpm}$ at $-5^{\circ} \mathrm{C}$ and dissolved in $1 \mathrm{ml}$ phosphate buffer $(\mathrm{pH} 7.0)$. The protein extract were stained using Coomassie Brilliant Blue G-250 (Sigma-Aldrich Product Code 27815) and the absorbency was recorded photometrically at $595 \mathrm{~nm}$ using spectronic 21D according to Bradford (1976).

\section{Determination of DNA content}

Root samples (1g) were ground with liquid nitrogen and genomic DNA was extracted by pre-warmed CTAB extraction buffer according to Isaac (1994) then mixed with an equal volume of chloroform-isoamyl alcohol (24:1), precipitated by isopropanol. Finally extracted DNA was washed by $70 \%$ ethanol. DNA was estimated by diphenylamine (DPA) colour reaction as previously described by Burton (1956). The absorbance was recorded at $595 \mathrm{~nm}$.

\section{Ultrastructure analysis}

Meristems samples (treated and control) were fixed in $2 \%$ glutaraldehyde in $0.05 \mathrm{~mol} \mathrm{~L}^{-1}$ sodium cacodylate buffer ( $\mathrm{pH} 6.9$ ), for $2 \mathrm{~h}$ at $4^{\circ} \mathrm{C}$, then washed three times in sodium cacodylate buffer and postfixed in $4 \%$ osmium tetraoxide for $1 \mathrm{~h}$ at $4^{\circ} \mathrm{C}$. Afterward, specimens were dehydrated in ethanol water series starting with $50 \%$ followed by passage through a graded propylene oxide ethanol series, the root tips were gradually infiltrated with Epon 812 resin by placing them for $3 \mathrm{~h}$ in each of series of resin/propylene oxide mixtures, ending by $100 \%$ resin. Finally, meristems were embedded in freshly prepared resin and polymerized in oven at $60^{\circ} \mathrm{C}$ for $48 \mathrm{~h}$ (Glińska \& Gabara, 2000). Sections $(1 \mu \mathrm{m})$ were cut with Reichert Ultra-microtome, mounted on copper grids and stained with $0.5 \%$ uranyl acetate and lead citrate for 30min (for each) according to Reynolds (1963). Observations were carried out using JEOL TEM 1010, Japan transmission electron microscope at $80 \mathrm{kV}$, Electron Microscope Unit, Center for Mycology and The Regional Biotehnology, Al Azhar University.

\section{Statistical analysis}

Data were expressed as mean \pm SD. The statistical significance of the differences in mean values between means of control group and those of treated groups was calculated by ANOVA and Dunnett T-test (Duncans multiple range test) where significance was accepted at $\mathrm{P} \leq 0.05$ and $\mathrm{P} \leq 0.01$. These were carried out using GraphPad (Version 4.0) with five replicates for each treatment.

\section{$\underline{\text { Results }}$}

\section{The $\mathrm{pH}$ value of solutions}

The results in Table 1 reveal the reversal relationship between the concentration of $\mathrm{DE}$ suspensions and their $\mathrm{pH}$ values.

TABLE 1. pH values of different concentrations of diatomaceous earth suspension.

\begin{tabular}{lc}
\hline DE concentration & pH value \\
\hline 0 & 7.09 \\
$10 \%$ & 7.33 \\
$30 \%$ & 6.49 \\
$60 \%$ & 5.05 \\
\hline
\end{tabular}

Cytogenetic analysis

Mitotic activity analysis

DE suspensions caused a gradually decrease in the mitotic activity of $V$. faba roots. Mitotic indices showed significantly suppression at levels $\mathrm{P} \leq 0.05$ and $\mathrm{P} \leq 0.01$ with increase in the concentrations and time of exposure to DE suspension. Table 2 showed the completely inhibition of the mitotic process after treatment with the highest concentration $(60 \%)$ for $12 \mathrm{~h}$. The highest ratio of MI scored $4.35 \%$ was achieved by treatment with $10 \% \mathrm{DE}$ suspension for $3 \mathrm{~h}$, while the lowest ratio was $2.44 \%$ observed after treatment with $60 \%$ DE suspension for $6 \mathrm{~h}$. This significantly decrease in mitotic indices was accompanied with an accumulation in significant metaphase stage at levels $\mathrm{P} \leq 0.05$ and $\mathrm{P} \leq 0.01$, which was time dependent. Treatment with $30 \%$ DE suspension for $12 \mathrm{~h}$ triggered the highest frequency of metaphase reaching $42.15 \%$, while treatment with $10 \%$ DE suspension for $3 \mathrm{~h}$ caused the lowest frequency of metaphase reaching 33.78 (Fig. 1). The significant increase of mitotic aberration at levels $\mathrm{P} \leq 0.05$ and $\mathrm{P} \leq 0.01$ was time and concentration dependent ranging from $18.04 \%$ to $51.82 \%$ (Table 2). Exposure of $V$. faba roots to different concentrations of $\mathrm{DE}$ suspension enhanced the formation of different types of mitotic aberrations like spindle disturbance, stickiness, bridge and laggards. The most representative types were illustrated in Fig. 2. 


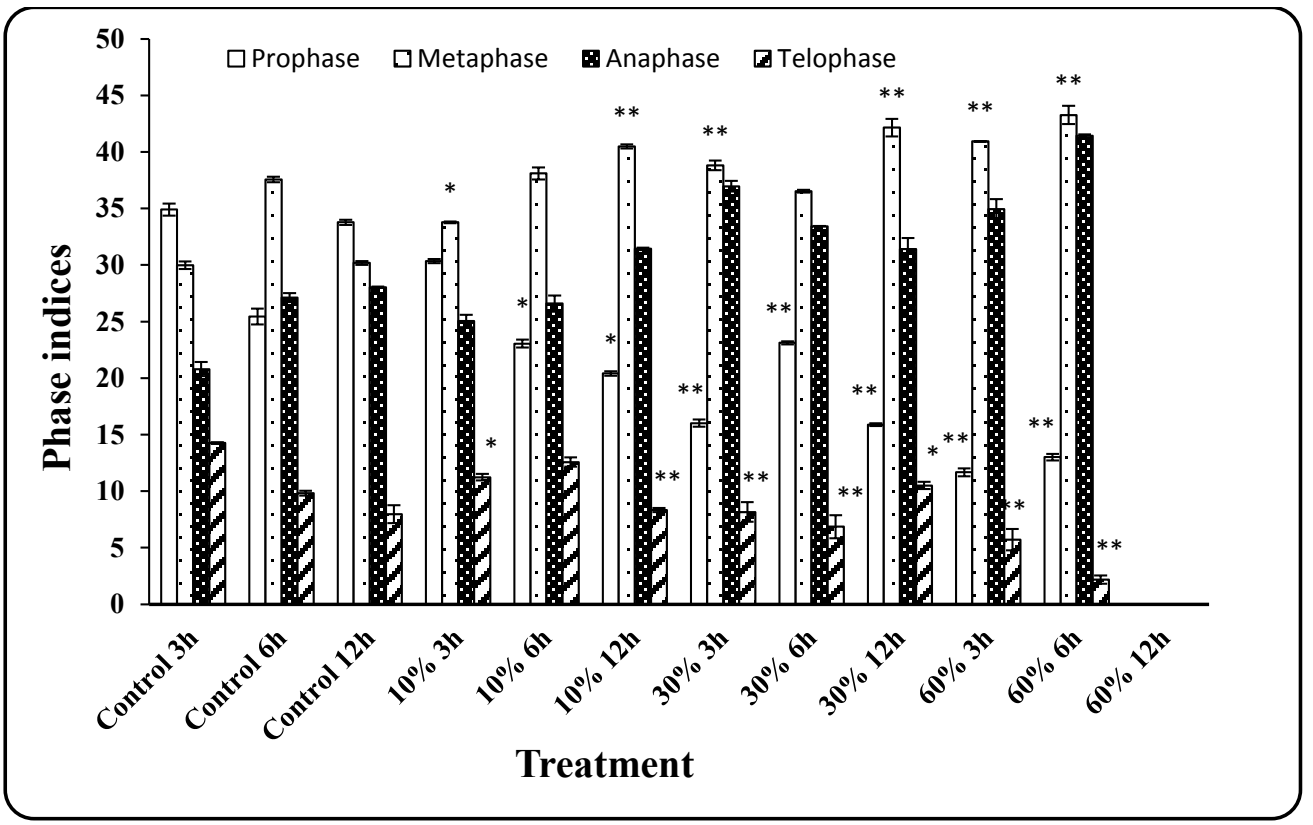

*Statistically significant at $\mathrm{P} \leq 0.05$

**Statistically significant at $\mathrm{P} \leq 0.01$

Fig. 1. Effect of diatomaceous earth suspension on mitotic phases of Vicia faba meristems.

TABLE 2. Effect of different concentrations of diatomaceous earth suspension and time exposure on mitotic indices (MI) and mitotic aberration of Vicia faba meristems.

\begin{tabular}{lccc}
\hline Treatment & Total No. of cells & Mitotic index \pm SD & Mitotic aberrations \pm SD \\
\hline Control & 1072 & & \\
$3 \mathrm{~h}$ & 1006 & $5.21 \pm 0.16$ & $8.60 \pm 0.56$ \\
$6 \mathrm{~h}$ & 1051 & $6.33 \pm 0.35$ & $13.09 \pm 1.20$ \\
$12 \mathrm{~h}$ & & & $10.66 \pm 0.98$ \\
\hline $10 \%$ & 1004 & $4.35^{*} \pm 0.37$ & $18.04 * * \pm 0.24$ \\
$3 \mathrm{~h}$ & 1120 & $3.86^{* *} \pm 0.21$ & $26.37^{* *} \pm 0.61$ \\
$6 \mathrm{~h}$ & 1063 & $2.79^{* *} \pm 0.09$ & $29.75^{* *} \pm 1.09$ \\
$12 \mathrm{~h}$ & & & $29.62^{* * \pm 0.53}$ \\
\hline $30 \%$ & 1078 & $3.76^{* * \pm 0.20}$ & $32.22^{* *} \pm 0.86$ \\
$3 \mathrm{~h}$ & 1003 & $3.64^{* * \pm 0.14}$ & $32.39^{* *} \pm 0.27$ \\
$6 \mathrm{~h}$ & 1062 & $3.06^{* * \pm 0.93}$ & \\
$12 \mathrm{~h}$ & & $46.55^{* *} \pm 0.74$ \\
\hline $60 \%$ & 1253 & $2.03^{* *} \pm 0.87$ & $51.82^{* *} \pm 0.09$ \\
$3 \mathrm{~h}$ & 1009 & $2.44^{* *} \pm 0.12$ & Toxic \\
$6 \mathrm{~h}$ & 1000 & Toxic & \\
$12 \mathrm{~h}$ & & & $($ complete inhibition in cell division) \\
\hline
\end{tabular}

*Significant from control at 0.05 level

**Significant from control at 0.01 level 

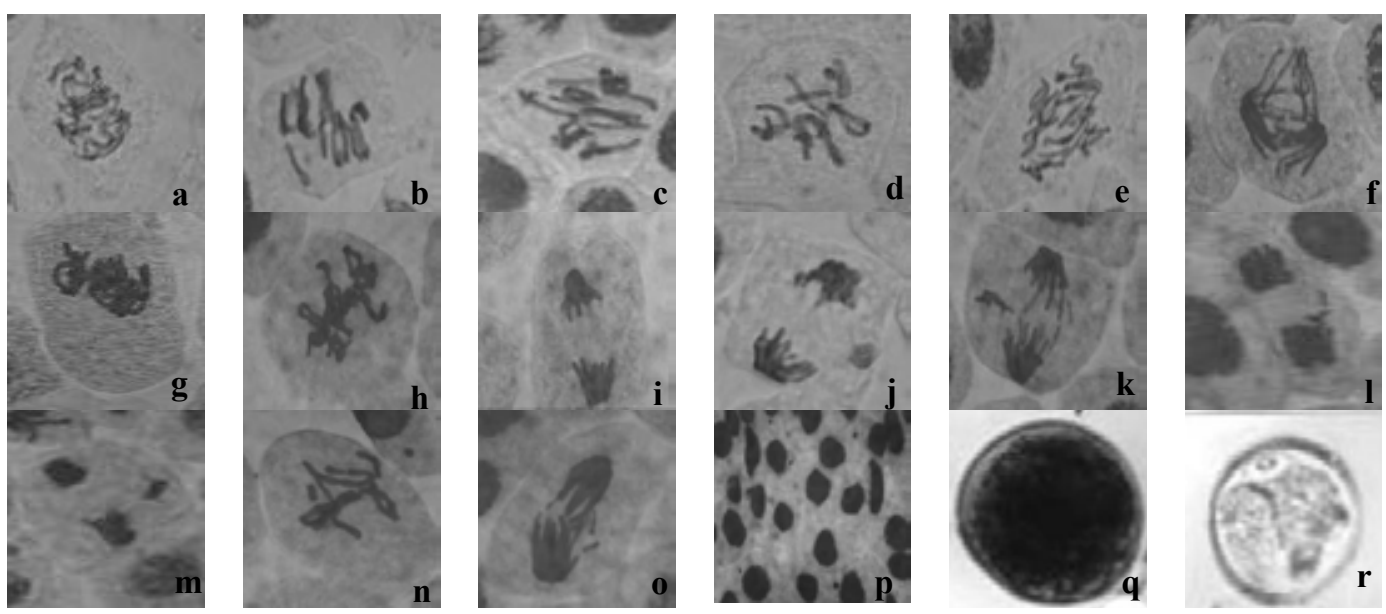

Fig. 2. Types of chromosomal aberrations induced in Vicia faba meristems treated with different concentrations of diatomaceous earth suspension $(X=400)$, a: Irregular prophase, $b-c:$ Disturbed metaphase, $d$ : c-Metaphase, e-f: Disturbed anaphase, g-h: Sticky metaphase, i: Sticky anaphase, j: Sticky anaphase with micronucleus, k: Anaphase with lagging chromosomes, l-m: Telophase with lagging chromosomes, n: Metaphase cell with chromosome's fragment, 0 : Anaphase cell with chromosome's fragment, p: Field of micronucleus in interphase cells, q: Viable pollen grain and r: Sterile pollen grain. test)

Determination of micronucleus (genotoxicity

The genotoxic strength of DE suspension was evaluated by micronucleus test. The percentage of micronucleus induction was time and concentration dependent. Treatment with $60 \%$ DE suspension for $12 \mathrm{~h}$ scored the highest frequency reaching $(23.99 \%)$, while $14.80 \%$ was the lowest micronucleus ratio detected after treatment with $10 \%$ for $3 \mathrm{~h}$ (Fig. 3). The induction of micronucleus was significant at level $\mathrm{P} \leq 0.01$.

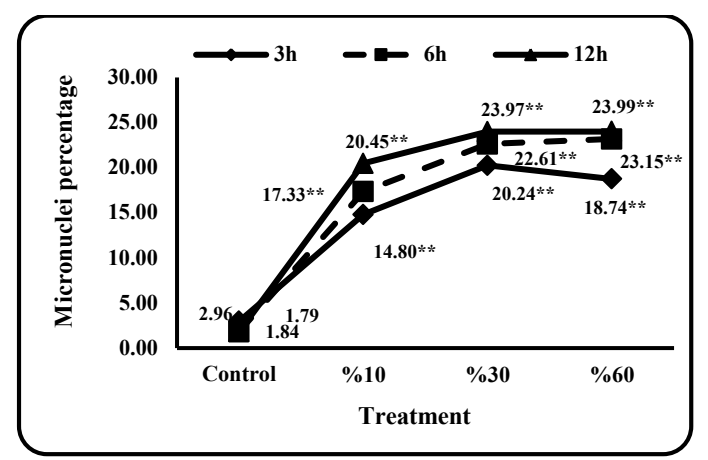

*Statistically significant at $\mathrm{P} \leq 0.05$

Fig. 3. Percentage of micronuclei induced in Vicia faba meristems treated with diatomaceous earth suspension.

\section{Determination of pollen sterility}

The DE suspensions enhanced pollen sterility in $V$. faba buds. The percentage of pollen sterility was varied from $19.4 \%$ to $52.2 \%$ in the treated samples as compared to $0 \%$ in the control. The frequency of pollen sterility increased in the concentration and time dependant manner and was significant at level $\mathrm{P} \leq 0.01$ (Fig. 4).

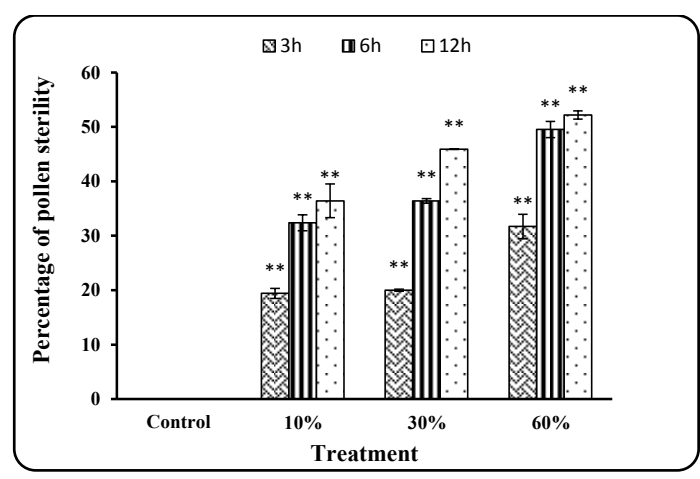

**Statistically significant at $\mathrm{P} \leq 0.01$

Fig. 4. Percentage of pollen sterility percentage induced in Vicia faba anthers treated with diatomaceous earth suspension.

\section{Biochemical analysis}

\section{Determination of protein content}

A general depressive effect on the formation of cellular protein was clearly observed after treatments with DE suspension on $V$. faba root cells compared to their respective control in dose dependent manner (Fig. 5). All results were significant at levels $\mathrm{P} \leq 0.05$ and $\mathrm{P} \leq 0.01$, except treatment with $10 \%$ of DE suspension for $3 \mathrm{~h}$ was non-significant. The maximum significant reduction $(1.53 \mathrm{mg} / \mathrm{g})$ was attained after the application of $60 \%$ of DE suspension for $12 \mathrm{~h}$. 


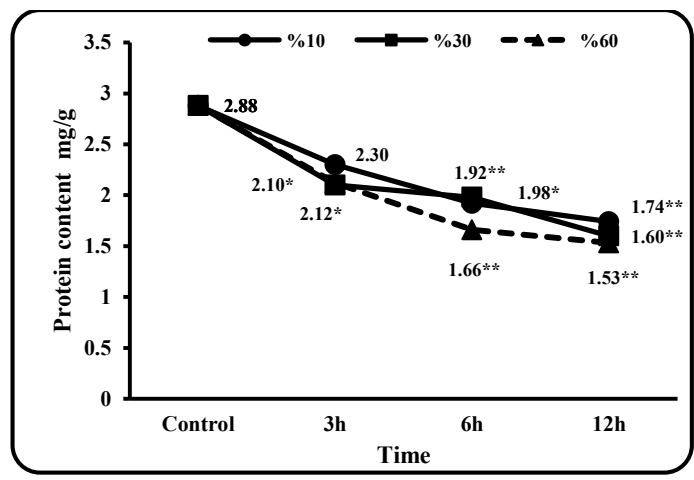

*Statistically significant at $\mathrm{P} \leq 0.05$

**Statistically significant at $\mathrm{P} \leq 0.01$

Fig. 5. Protein content induced in Vicia faba roots treated with diatomaceous earth suspension.

\section{Determination of DNA content}

Variations in DNA content induced after the exposure to DE suspension were declared in Fig. 6. The exposure to DE suspension caused highly significant decline in DNA content at levels $\mathrm{P} \leq 0.05$ and $\mathrm{P} \leq 0.01$. These variations were time and concentration dependent. Treatment with of $10 \%$ of DE suspension for $3 \mathrm{~h}$ induced the highest amount of DNA reaching $2.20 \mu \mathrm{g} / \mathrm{g}$. While, the least value $(1.41 \mu \mathrm{g} / \mathrm{g})$ was achieved by treatment with $60 \%$ of DE suspension for $12 \mathrm{~h}$.

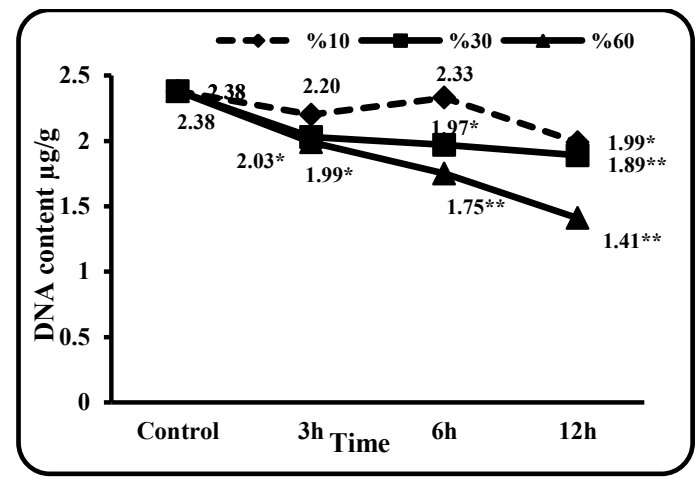

*Statistically significant at $\mathrm{P} \leq 0.05$

**Statistically significant at $\mathrm{P} \leq 0.01$

Fig. 6. DNA content induced in Vicia faba roots treated with diatomaceous earth suspension.

\section{Ultrastructure analysis}

The cytoplasm of control cells showed normal distribution of cellular organelles; it contains all cellular organelles such as a large nucleus, dense cytoplasm and well organized organelles as mitochondria, proplastids and ribosomes (Fig. 7a).
DE suspensions caused a gradually changes on $V$. faba sub-cellular organelles, which were dose and time dependent. Concentrations of 10 and $30 \%$ for $3 \mathrm{~h}$ and $6 \mathrm{~h}$, respectively of DE suspensions initiate several evidences of cellular toxicity such as dilation of ER lumens, disruption of the mitochondrial membrane and cristae were poorly present (Fig. $7 \mathrm{~b}$ and $\mathrm{c}$ ). The nuclear envelope was disintegrated in some cells and there was accumulation of cell's remains and organelle's debris inside vacuoles after treatment with $60 \%$ DE for $6 \mathrm{~h}$ (Fig. $7 \mathrm{~d}$ and e). Finally, the vacuolar system extremely expanded and causing cytoplasm became structure-less after $12 \mathrm{~h}$ exposure to $60 \%$ DE (Fig. $7 \mathrm{f}$ ).

\section{Discussion}

Raw DEs are mainly composed of silica but contain a substantial amount of impurities, largely exceeding even what was found to modulate toxicity in commercial quartz dusts (Fubini et al., 2004). The presence of such impurities such as Al, $\mathrm{Cu}, \mathrm{Fe}$ and $\mathrm{Pb}$ may cause an effect of calcination on hydrophilicity and surface reactivity, different from those observed on crystalline silica specimens of mineral origin, causing pathological effects of silica dusts.

In the present study the toxicity of $\mathrm{DE}$ suspension on plant cell was proven by several tests. Root tip cells of $V$. faba constitute an excellent system for cytogenetic tests (John \& Abraham, 1991). The mitosis assay was used to assess the ability of $V$. faba meristematic cells to perform their normal mitotic division. Herein, the mitotic index of treated of $V$. faba was decreased significantly in comparison to control group. This cytological alterations induced in $V$. faba seem to be due to mitodepressive properties of DE suspension as previously reported by Elias et al. (2006) who declared that silica particles in DE have effects on the mitotic spindle and on the chromosome congression and segregation during mitosis resulting in cell death or genomic changes of some surviving cells. In addition, previous studies by Fubini et al. (2001) and Elias et al. (2002) showed that, like crystalline silica, some commercial DEs were a potent prooxidant causing cytotoxiy and morphological transformation of Syrian hamster embryo (SHE) cells. It might have toxic effect on cell division and might cause a physiological change in the nucleoprotein or denaturation of proteins reflected as chromosomal aberrations. 


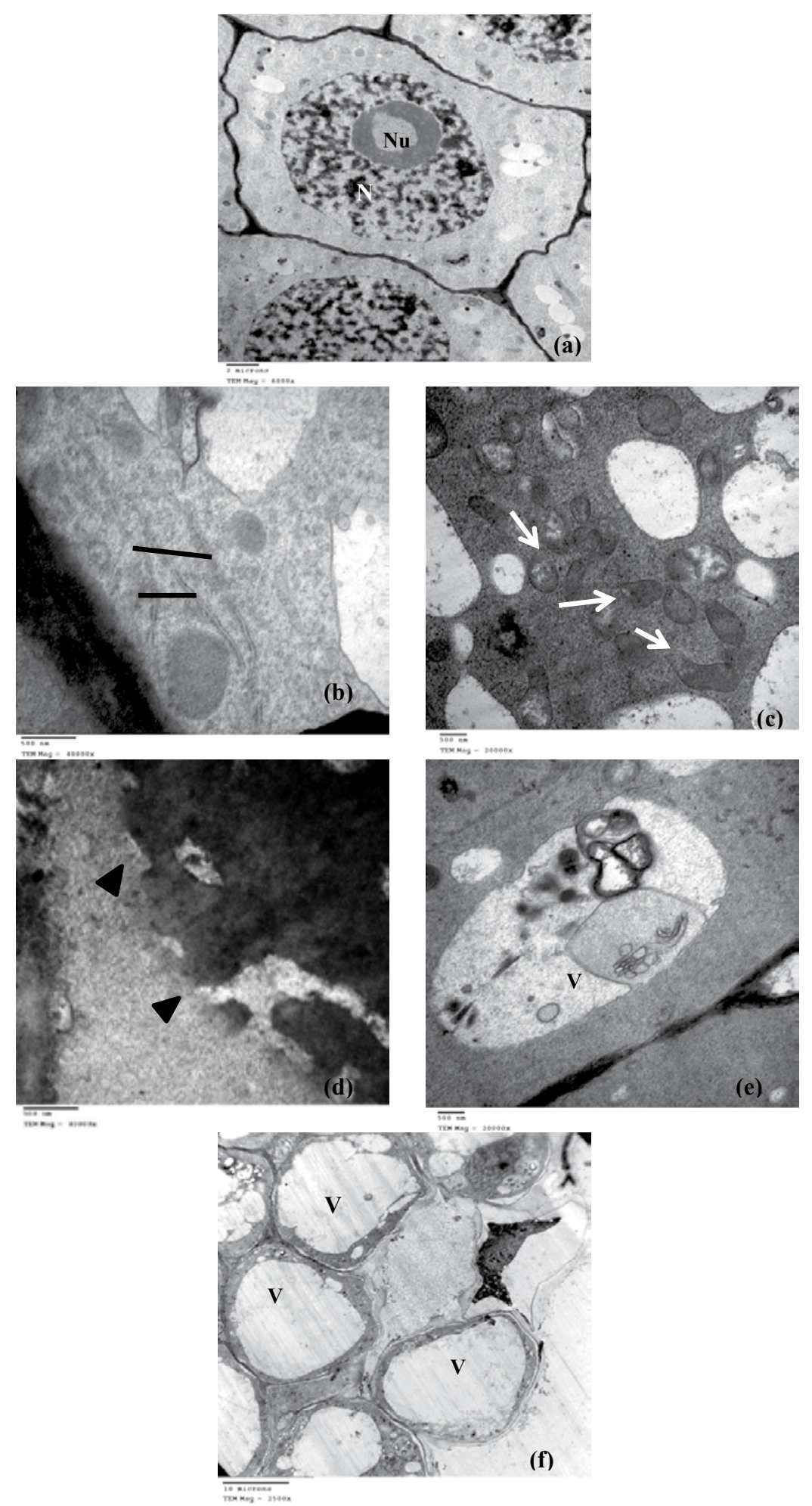

Fig. 7. Electron micrographs of control and treated root meristems of Vicia faba, a: Control root cell, b: Roots treated with $10 \%$ DE for $3 \mathrm{~h}$ show dilated ER lumen, c: Roots treated with $30 \% \mathrm{DE}$ for $6 \mathrm{~h}$ show rupture of mitochondria's membrane and vacuolization of the cytoplasm, d: Roots treated $60 \%$ DE for $6 \mathrm{~h}$ show disintegration in nuclear envelope, e: Roots treated $60 \% \mathrm{DE}$ for $6 \mathrm{~h}$ show degenerated organelles and cell's debris inside the vacuole, f: Roots treated $60 \%$ DE for $12 \mathrm{~h}$ show complete vacuolization of the cytoplasm (N: Nucleus, Nu: Nucleolus, line: Dilated endoplasmic reticulum, arrow: Rupture mitochondrion, arrow head: Disintegration in nuclear envelope and V: Vacuole ). 
The present study revealed that the $\mathrm{pH}$ value of DE suspension was decrease (acidity increase) by increasing of its concentration. This acidity property may be the cause of the mitodepressive effect of DE suspension. This explanation in accordance with Elias et al. (2006) who stated that, cytotoxicity of DE would be related to some physicochemical features, such as micromorphology, surface charges and in particular the degree of acidity.

The increase in the percentage of mitotic abnormalities of $V$. faba roots occurred after DE treatment indicated that DE can lead to mutation or can act as clastogene, the same result reported by Njoku et al. (2011), who found that altered chromosomes may have altered DNA and gene sequences. Elias et al. (2006) reported that, there was increase in cell division aberrations induced by samples of DE in Syrian hamster embryo cells and the most frequent types of aberrations observed were monopolar or tripolar spindles, mitotic spindle disturbance and some bridges in anaphase and scattered chromosomes were also observed.

In present study, spindle disturbance and chromosome stickiness were the major chromosomal anomalies indicating that DE suspension could be interfered with the polymerization and depolymerization of microtubules (Seth et al., 2008). Ozmen et al. (2007) revealed that antimitotic agents probably affect the cytoskeleton or tubulin polymerization/ depolymerisation and affecting physical and chemical properties of DNA, protein, or both ultimately leading to improper folding of chromatin (Teerarak et al., 2010). Spindle disturbance may be caused by inhibition of DNA synthesis at $\mathrm{S}$-phase of cell cycle as reported by Kumari et al. (2011). Disturbance and C-mitosis can be caused by changing in the spindle structure thus hindering spindle polymerization and/or spindle poisons due to twisting of polypeptides forming spindle apparatus (El-Ghamery et al., 2000). Chromosome bridges are formed due to strong connection between chromatin fibers which join sister chromatids at metaphase and hold them till late anaphase or telophase. This strong connection may prevent the correct separation of joined chromatids during mitosis causing breakdown of chromatids at or near the points of connection at anaphase giving rise to fragments of chromosomelike structure (Mohanty et al., 2004).
The ability of DE suspension to accumulate cells at metaphase and blocked metaphase/ anaphase transition by increasing the time of exposure and concentration proved that the tubulin subunits was the as main target of DE suspension as suggested by Sorger et al. (1997). They showed that most microtubule-damaging agents that inhibit normal spindle formation, either by increasing microtubule polymerization/ depolymerisation stability, can arrest cells at metaphase. The deficiency in tubulin equilibrium by means of polymerization and depolimerization of microtubules inhibits phragmoplasts's formation results in failure of the cytokinesis process (Murata et al., 2013).

The results of the present study showed that DE suspension induced a significant increase of the $\mathrm{MN}$ frequency with increase of fragment and lagging frequencies in $V$. faba root tips. These demonstrate that DE suspension is a clastogen that induces chromosome/ chromatid breaks and lagging chromosomes. Several authors deduced that the occurrence of micronuclei is considered as an indicator of clastogenic and aneugenic effects (Walker et al., 1996 and Van Goethem et al., 1997). MN can cause genetic damage by eliminate some of genetic material, which present and highly compacted within micronuclei, from the cell as reported by Fernandes et al. (2007) and Sobieh et al. (2016). The mechanisms responsible for $\mathrm{MN}$ have not been yet fully understood. Fenech (2011) indicated that micronuclei can be caused due to presence of DNA double-strand breaks, which cannot be able to segregate in the daughter nuclei at telophase stage. The presence of these DNA fragments might be as a result of the lack of spindle attachment during the segregation process of chromosomes in anaphase. In another point of view, Yi et al. (2010) stated that the induction of $\mathrm{MN}$ indicates the defects in cell cycle checkpoints in $V$. faba root cells that may be due to the entry of some mitotic cells into mitosis with DNA damage.

The concentration and time dependent reduction in pollen fertility may be a demonstration of persistent chromosomal abnormalities in the treated $V$. faba plants. The pollen sterility caused by $\mathrm{DE}$ suspension may be due to a gene mutation as reported by Gulfishan et al. (2012). Dose dependent pollen sterility was also reported by Bhat et al. (2006) in $V$. faba and by Razu et al. (2012) in Triticum durum. 
The suppression effect of DE suspension on the mitotic activity of treated $V$. faba was accompanied with a depressive action on DNA and protein contents by increasing time of exposure and concentration of DE suspension. This significant decrease reflects a highly inhibition of DNA and protein synthesis. The previous hypotheses by Schneiderman et al. (1971), Tawab et al. (2004) and Sobieh et al. (2014) suggested that, the inhibition of mitosis may be due to an inhibitory effect on DNA and protein synthesis. From the present ultrastructure result, the presence of large vacuole reflects the presence of proteolytic enzymes. Hosseini \& Mulligan (2002) proved that increasing in proteolytic activities can cause decrease in the intracellular protein content. Moreover, mitochondria were obviously damaged, which in turn can reduce ATP level in the cell that is required for DNA and protein synthesis.

The induced ultrastructural changes in treated $V$. faba roots are resemble to those of metal toxicity stress in plants. The common poison symptoms were swollen mitochondria, disruption of the membranes, and dilation of organelles. The present results showed that root tip cells had a rapid and effective defence system against DE suspension toxicity involving ER and mitochondria, which may be one mechanism accounting for lower toxicity of DE suspension. The ultrastructural response of ER towards stress by DE suspension was displayed by the noticeable dilation of the ER lumen. This dilation of ER lumen is thought to be necessary to accommodate increasing amounts of lumenal constituents; in particular those are being synthesized to manage ER stress to deal with toxic conditions (Despa, 2009). Similar effects have also been confirmed in plant cells, yeast cells and mammalian cells in vitro and in vivo (Zuber et al., 2004; Bernales et al., 2006 and Hartley et al., 2010). It is also known that ER-targeted stress can activate $\mathrm{Ca}^{2+}$ efflux from the ER; this $\mathrm{Ca}^{2+}$ is then redistributed to the mitochondria and leads to cell death (Walter \& Hajnoczky, 2005).

The obvious alterations in mitochondria of treated $V$. faba like swelling and disintegration of cristae demonstrated the effect of DE suspension on the mitochondrial respiration process (Foissnor, 1984). The damage of mitochondria in present study presumably caused by the high reactive oxygen species (ROS) production as suggested by Gabara et al. (2003) and Patnaik et al. (2013), who found that swelling and disintegration of mitochondrial cristae were accompanied with increase in ROS level and changes in activities of antioxidant defence system. Moreover, Koyro (1997) proved that the decrease in electron density within the matrix of the mitochondria reflect a degeneration of the mitochondria. Lemasters et al. (1997) revealed that toxic factors could cause the same ultrastural changes in mitochondria permeability. The formation of ROS might cause serious cellular damage such as peroxidation of lipid membranes (Ding \& Ong, 2003), which in turn can cause structural damage to cell's membranes and organelles's membranes (Popova $\&$ Popov, 2004). Formerly, Elias et al. (2006) have proved the ability of the DE dust to release hydroxyl $(\cdot \mathrm{OH})$ radicals, therefore changes in the integrity of mitochondria's membranes may be the result of oxidative stress induced by $\mathrm{DE}$ suspension.

The majority of nuclei in $V$. faba root cells appeared ultrastructurally unchanged, without displaying chromatin condensation and irregular shape as previously noted in cotton cells when treated with chromium (VI) by Daud et al. (2014). Nevertheless, the disruption of nuclear envelope was detected in some nuclei. This disruption presumes the onset of cell death as proposed by Madeo et al. (1997).

The vacuole is the final destination for all toxic substances that plants can be exposed to, and the vacuoles of root cells are the major sites of toxic materials sequestration (Clemens, 2006). Cytoplasmic vacuolization and the increased level of electron-dense granules in vacuoles can be thought of as a detoxification pathway for preventing cell damage and retaining the toxic agents in vacuoles (Einicker-Lamas et al., 2002). Sharma \& Dubey (2005) showed that the vacuole is the major part of the cell, which $\mathrm{Pb}$ was sequestered within in the form of complexes. As well, vacuolization may be a response to membrane system damage induced by ROS caused by toxicity of DE suspension (Kim \& Park, 2010). The accumulation of wastes and organelle's debris inside vacuoles after treatment with $60 \%$ DE suspension for $6 \mathrm{~h}$ reflect a significant role of detoxification that may induce by cells against DE suspension through autophagy or to prevent free circulation of DE particles (Eleftheriou et al., 2015). Treatment with $60 \%$ DE suspension for 
$12 \mathrm{~h}$ shows complete vacuolization of the cell. The vacuolization shows autophagy is activated as an adaptive catabolic process in response to different forms of metabolic stress as stated by Levine \& Kroemer (2008) and may protect plant cells from stress. These ultrastructural changes in $V$. faba cells were consistent with the symptoms of cell necrosis (Noodén, 2004). In addition, Mahakhode \& Somkuwar (2013) noted that, various structural disturbances in cell organelles translated into physiological and metabolic events leading to the slowing down of the growth of the plant and finally to its death.

\section{Conclusion}

This work provides the evidence of the mitodepressive and genotoxic potencies of DE suspension on plant cells and also confirms the efficiency of the plant cytogenetic assays on monitoring the genotoxicity and cytotoxicity of different agents. Since the plant system can detect the genotoxicity and cytotoxicity more efficiently and quickly than animal bioassays, we could use these simple and economical plant bioassays for clastogen screening and environmental monitoring in general.

DE suspension inhibits mitotic process of V. faba and exhibits mitotic arrest in metaphase associated with spindle disturbance. DE suspension obstructs DNA and protein synthesis, as well as caused alteration in organelles ultrastructure leads to significant inhibition of cell division. Thus, DE products should be considered as a set of silica-based potentially toxic materials, apart from the crystalline silica dusts of mineral origin. In long time exposure conditions, a particular concern should be given to the finer fraction of the particles which have a higher surface reactivity. Therefore, in the absence of well-defined molecular mechanisms of silica toxicity, risk evaluation procedures require to perform physicochemical and cellular tests on each DE sample.

Acknowledgements: The author would like to thank Prof. Dr. Thoria Rashad for her effort in revising this work.

\section{References}

Bernales, S., McDonald, K.L. and Walter, P. (2006) Autophagy counterbalances endoplasmic reticulum expansion during the unfolded protein response. PLoSBiol, 4, e423.

Bhat, T.A., Khan, A.H. and Parveen, S. (2006) Effect of gamma rays on certain cytomorphological parameters in two varieties of Vicia faba L. $A d v$. Plant Sci. 19, 227-232.

Bradford, M.M. (1976) A rapid and simple method for the quantitation of microgram quantities of protein utilizing the principle of protein-dye binding. Analyt. Bioch. 72, 248-254.

Burton, K. (1956) A study of the condition and mechanism of the diphenylamine reaction for the colorimeteric estimation of DNA. Bioch. J. 62, 315-323.

Chanbang, Y., Arthur, F.H., Wilde, G.E. and Throne, J.E. (2007) Efficacy of diatomaceous earth to control Rhyzopertha dominica (F.) (Coleoptera: Bostrichidae) in rough rice: Impacts of temperature and relative humidity. Crop Protec, 26, 923-929.

Clemens, S. (2006) Toxic metal accumulation, responses to exposure and mechanisms of tolerance in plants. Bioch. 88,1707-19.

Daud, M.K., Mei, L., Variath, M.T., Ali, S., Li, C., Rafiq, M.T. and Zhu, S.J. (2014) Chromium (VI) uptake and tolerance potential in cotton cultivars: Effect on their root physiology, ultramorphology, and oxidative metabolism. BioMed Res Inter. doi:org/10.1155/2014/975946

Despa, F. (2009) Dilation of the endoplasmic reticulum in beta cells due to molecular overcrowding? Kinetic simulations of extension limits and consequences on proinsulin synthesis. Biophys. Chem. 140, 115-121.

Ding, W.X. and Ong, C.N. (2003) Role of oxidative stress and mitochondrial changes in cyanobacterialinduced apoptosis and hepatotoxicity. FEMS Microbiol. Lett. 220,1-7.

Einicker-Lamas, M., Mezian, G.A., Fernandes, T.B., Silva, F.L., Guerra, F., Miranda, K., Attias, M. and Oliveira, M.M.M. (2002) Euglena gracilis as a model for the study of $\mathrm{Cu}^{2+}$ and $\mathrm{Zn}^{2+}$ toxicity and accumulation in eukaryotic cells. Environ Poll, 120, 779-86.

Eleftheriou EP, Adamakis IS, Panteris E, Fatsiou M 
(2015) Chromium-induced ultrastructural changes and oxidative stress in roots of Arabidopsis thaliana. J. Mol. Sci. 16, 15852-15871.

El-Ghamery, A.A., El-Nahas, A.I. and Mansour, M.M. (2000) The action of atrazine herbicide as an inhibitor of cell division on chromosomes and nucleic acids content in root meristems of Allium cepa and Vicia faba. Cytologia, 65, 277-287.

Elias, Z., Poirot, O., Daniére, M.C., Terzetti, F., Béna, F., Fenoglio, I. and Fubini, B.(2002) Role of iron and surface free radical activity of silica in the induction of morphological transformation of Syrian hamster embryo cells. Ann. Occupat. Hyg. 40, 53-57.

Elias, Z., Poirot, O., Fenoglio, I., Ghiazza, M., Daniére, M., Terzetti, F., Darne, Ch., Coulais, C., Matekovits, I. and Fubini, B. (2006) Surface reactivity, cytotoxic and morphological transforming effects of diatomaceous earth products in Syrian hamster embryo cells. Toxicol. Sci. 91, 510-520.

Faulde, M.K., Tisch, M. and Scharninghausen, J.J. (2006) Efficacy of modified diatomaceous earth on different cockroach species (Orthoptera, Blattellidae) and silverfish (Thysanura, lepismatidae). J Pest Sci. 79,155-161.

Fenech, M. (2011) Molecular mechanisms of micronucleus, nucleoplasmic bridge and nuclear bud formation in mammalian and human cells. Mut. 26, 125-132.

Fernandes, T.C.C., Mazzeo, D.E.C. and MarinMorales, M.A. (2007) Mechanism of micronuclei formation in polyploidizated cells of Allium cepa exposed to trifluralin herbicide. Pest Biochem. Physiol. 88, 252-259.

Foissnor, I. (1984) Effect of 3-(3,4-dichlorophenyl)1,1-dimethylurea (DCMU) on photosynthesis and respiration of Nitella Dactyl cells. Pest Biochem. Physiol. 22, 346.

Freo, J., Moraes, L., Santetti, G., Gottmannshausen, T., Elias, M.C. and Gutkoski, L.C. (2014) Physicochemical characteristics of wheat treated with diatomaceous earth and conventionally stored. Ciênc. Agrotec. Lavras, 38, 546-553.

Fubini, B. and Hubbard, A. (2003) Reactive oxygen species (ROS) and reactive nitrogen species (RNS) generation by silica in inflammation and fibrosis. Free Rad. Biol. Med. 34, 1507-1516.

Fubini, B., Fenoglio, I., Elias, Z. and Poirot, O. (2001) Variability of biological responses to silicas: Effect of origin, crystallinity, and state of surface on generation of reactive oxygen species and morphological transformation of mammalian cells. J. Environ. Pathology Toxicol. Oncol. 20, 95-108.

Fubini, B., Fenoglio, I., Ceschino, R., Ghiazza, M., Martra, G., Tomatis, M., Borm, P., Schins, R. and Bruch, J. (2004) Relationships between the state of the surface of four commercial quartz flours and their biological activity in vitro and in vivo. Inter. $J$. Hygi. Environ. Health, 207, 89-104.

Gabara, B., Skłodowska, M., Wyrwicka, A., Glinśka, S. and Gapinśka, M.(2003) Changes in the ultrastructure of chloroplasts and mitochondria and antioxidant enzyme activity in Lycopersicon esculentum Mill. leaves sprayed with acid rain. Plant Sci. 164, 507-516.

Glińska, S. and Gabara, B. (2000) Localization of selenium deposits in meristematic cells of Allium sativum L. roots treated with selenium salts. Folia Histochem. Cytobiol. 38,143-147.

Gulfishan, M., Khan, A.H., Jafri, I.F. and Bhat, T.A. (2012) Assessment of mutagenicity induced by MMS and DES in Capsicum annuum L. Saudian J. Biol. Sci. 19, 251-255.

Hartley, T., Siva, M., Lai, E, Teodoro, T., Zhang, L. and Volchuk, A. (2010) Endoplasmic reticulum stress response in an INS-1 pancreatic $\beta$-cell line with inducible expression of a folding deficient proinsulin. BMC Cell Biol. 11, 59.

Hosseini, S.A., Bazrafkan, S.,Vatandoost, H., Abaei, M.R., Ahmadi, M.S., Tavassoli, M. and Shayeghi, M. (2014) The insecticidal effect of diatomaceous earth against adults and nymphs of Blattella germanica. Asian Pac. J. Trop. Biomed. 4, S228-S232.

Hosseini, R. and Mulligan, B.J.(2002) Application of rice (Oryza sativa L.) suspension culture in studying senescence in vitro (I). Single strand preferring nuclease activity. Electro J. Biotechnol. 5, 42-54.

IARC (1997) "IARC Monographs on the Evaluation of 
Carcinogenic Risks to Humans". Vol. 68. Silica, Some Silicates. Coal Dust and para-Aramid Fibrils. International Agency for Research on Cancer, Lyon, France.

Isaac, P.G. (1994) "Methods in Molecular Biology". Protocols for nucleic acid analysis by nonradioactive probes, Humana Press Inc, Totowa, New Jersey.

John, A.T. and Abraham, S. (1991) Cytological changes produced by red pepper in mitotic cells of Vicia faba L. Caryol. 44, 325-331

Kavallieratos, N.G., Athanassiou, C.G., Paschalidou, F.G., Andris, N.S. and Tomanovic, Ž.(2005) Influence of grain type on the insecticidal efficacy of two diatomaceous earth formulations against Rhyzopertha dominica (F) (Coleoptera: Bostrychidae). Pest Manag. Sci. 61, 660-666.

Kim, I. and Park, S. (2010) Ultrastructural characteristics of three chenopod halophytes lacking salt excretion structures. J. Plant Biol. 53, 314-320.

Korunic, Z. (1998) Diatomaceous earths, a group of natural insecticides. J. Stor. Prod. Res. 34, 87-97.

Koyro, H.W. (1997) Ultrastructural and physiological changes in root cells of Sorghum plants [Sorghum bicolorx $\mathrm{S}$. sudanensis cv. Sweet Sioux) induced by NaCl. J. Exper. Bot. 48, 693-706.

Kumari, M., Sinhal, V.K., Srivastava, A. and Singh, V.P. (2011) Cytogenetic effects of individual and combined treatment of $\mathrm{Cd}^{2}+, \mathrm{Cu}^{2}+$ and $\mathrm{Zn}^{2}+$ in Vigna radiata (L.) wilczeck. J. Phytol. 3, 38-42.

Lemasters, J., Nieminen, A., Qian, T., Trost, L. and Herman, B. (1997) The mitochondrial permeability transition in toxic, hypoxic and reperfusion injury. Mol. Cell Biochem. 174, 159-165.

Levine, B. and Kroemer, G. (2008) Autophagy in the pathogenesis of disease. Cell, 132, 27-42.

Ma, T.H., Xu, Z., Xu, C., McConnell, H., Rabago, E.V., Arreola, G.A. and Zhang, H. (1995) The improved Allium/Vicia root tip assay for clastogenicity of environmental pollutants. Mut. Res. 334, 185-195.

Madeo, F., Fröhlich, E. and Fröhlich, K.U. (1997) A yeast mutant showing diagnostic markers of early and late apoptosis. J. Cell Biol. 139, 729-734.
Mahakhode, R.H. and Somkuward, S.R. (2013) Mitotic abnormalities induced by glyphosate in Psoralea corylifolia L. Inter. J. Curr. Pharmaceut. Res. 5, 46-48.

Mohanty, S., Das, A.B., Das, P. and Mohanty, P. (2004) Effect of a low dose of aluminium on mitotic and meiotic activity, 4C DNA content, and pollen sterility in rice, Oryza sativa L. cv. Lalat. Ecotoxicol. Environ. Safety, 59, 70-75.

Murata, T., Sano, T., Sasabe, M., Nonaka, Sh., Higashiyama, T., Hasezawa, S., Machida, Y. and Hasebe, M. (2013) Mechanism of microtubule array expansion in the cytokinetic phragmoplast. Nat Commun. 4,1967.

Nattrass, C., Horwell, C.J., Damby, D.E., Kermanizadeh, A., Brown, D.M. and Stone, V. (2015) The global variability of diatomaceous earth toxicity: A physicochemical and in vitro investigation. $J$. Occupat. Med. Toxicol. 10, 23.

Njoku, K.L., Akinola, M.O. and Oshodin, O.R. (2011) Phytotoxicity assay of crude oil using different accessions of Sorghum bicolorIranica. J. Ener. Environ. 2, 235-243.

Noodén, L.D. (2004) "Plant Cell Death Processes". Academic Press, London.

Ozmen, A., Basbulbul, G. and Aydin, T. (2007) Antimitotic and antibacterial effects of the Nigella sativa L. seed. Caryol. 60, 270-272.

Patnaik, A.R., Achary, V.M.M. and Panda, B.B. (2013) Chromium (VI)-induced hormesis and genotoxicity are mediated through oxidative stress in root cells of Allium cepa L. Plant Growth Reg. 71, 157-170.

Popova, M.P. and Popov, C.S. (2004) Damage to subcellular structures evoked by lipid peroxidation. Neuropsychopharmacol. 24, 420-429.

Razu, M.H., Zaman, S., Akhter, R., Rahma, M.M., Hamidur, R.M., Mazid, M.A. and Kabir, G. (2012) Morphological and cytological effects of two herbicides on tetraploid wheat (Triticum durum L.). J. Biol. Sci. 20, 143-151.

Reynolds, E. (1963) The use of lead citrate at a high pH as an electron-opaque stain in electron microscopy. J. Cell Biol. 17, 208-212. 
Schneiderman, M.H., Dewey. W.C. and Highfield, D.P. (1971) Inhibition of DNA synthesis in synchronized Chinise hamster cell treated in G1 with cycloheleximide. Exper. Cell Res. 67,147-155.

Seth, C.S., Misra, V., Chauhan, L.K.S. and Singh, R.R. (2008) Genotoxicity of cadmium on root meristem cells of Allium cepa: Cytogenetic and Comet assay approach. Ecotoxicol. Environ. Saft. 71,711-716.

Sharma, P. and Dubey, R.S. (2005) Lead toxicity in plants. Brazil J. Plant Physiol. 17, 35-52.

Snetsinger, R. (1988) Report on shellshock insecticide. Report of Department of Entomology, Pennsylvania State University, University Park, PA 16802

Sobieh, Sh.S., Tawab, S.A. and Fahmy, D.M. (2014) Deregulation of mitosis progression and cytotoxic effect triggered in Allium cepa L. roots by Rubus sancatus Schreber Extract. Life Sci. J. 11, 10471058.

Sobieh, Sh.S., Zeinab, M.H.Kh., Abeer, A.R. and Naglaa, A.N.Y. (2016) In vitro and in vivo genotoxicity and molecular response of silver nanoparticles on different biological model systems. Caryol. 69,147161.

Sorger, P.K., Dobles, M., Tournebize, R. and Hyman, A.A. (1997) Coupling cell division and cell death to microtubule dynamics. Curr. Opin Cell Biol. 9, 807-814.

Subramanyam, B.H., Swanson, C.L., Madamanchi, N. and Norwood, S. (1994) Effectiveness of Insecto, a new diatomaceous earth formulation, in suppressing several stored-grain insect species. In: Proceedings of $6^{\text {th }}$ International Working Conference Storedproducts Prot. Highley, E., Wright, E.J., Banks, J.H., Champ, BR (Ed.). CAB International, Wallingford, Oxon, UK, pp 650-659.

Subramanyam, B.h. and Roesli, R. (2000) Inert dusts. In: "Alternatives to Pesticides in Stored-Product",
Subramanyam, Bh., Hagstrum, D.W. (Ed.), pp 321380. IPM Dordreecht: Kluwer Academic Publishers.

Tawab, S.A.F., Adam, Z.M. and Selmi, S.h. (2004) Suppression of mitotic process associated with metaphase arrest of Allium cepa L. roots using. I. Rosmarinus officinalis L. water extract. Inter. $J$. Agric. Biol. 6, 690-698.

Teerarak, M., Laosinwattana, C. and Charoenying, P. (2010) Evaluation of allelopathic, decomposition and cytogenetic activities of Jasminum officinale L. f. var. grandiflorum (L.) Kob. on bioassay plants. Biores. Technol. 101, 5677-5684.

Van Goethem, F., Lison, D. and Kirsch-Volders, M. (1997) Comparative evaluation of the in vitro micronucleus test and the alkaline single cell gel electrophoresis assay for the detection of DNA damaging agents: Genotoxic effects of cobalt powder, tungsten carbide and cobalt-tungsten carbide. Mut Res. 392, 31-43.

Walker, J.A., Boreham, D.R., Unrau, P. and Duncan, A.M.V. (1996) Chromosome content and ultrastructure of radiation-induced micronuclei. Mut. 11, 419-424.

Walter, L. and Hajnoczky, G. (2005) Mitochondria and endoplasmic reticulum: The lethal interorganelle cross-talk. J. Bioenerget. Biomemb. 37, 191-206.

Yi, M., Yi, H., Honghai, L. and Wu, L. (2010) Aluminum induces chromosome aberrations, micronuclei, and cell cycle dysfunction in root cells of Vicia faba. Environ. Toxicol. 25, 124-129.

Zuber, C., Fan, J.Y., Guhl, B. and Roth, J. (2004) Misfoldedproinsulin accumulates in expanded preGolgi intermediates and endoplasmic reticulum subdomains in pancreatic beta cells of Akita mice. FASEB J. 18, 917-919.

(Received 7/5/2018; accepted 7/9/2018) 


\section{دراسة قدرة معلق diatomaceous earth على سمية و تثبيط الأنقسام الميتوزى معتمدا على التجارب الحيوية النباتية شيماء سلمي صبيح قسم النبات ــكلية البنات للاداب و العلوم و التربية ـ جامعة عين شمس ـ القاهره ـ مصر.}

أظهرت العديد من الدر اسات السابقة قدرة (Mozambique diatomaceous earth DE) للقضاء على بعض تلقض

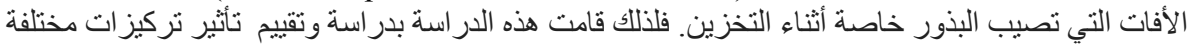
(10، 30 و 60\%) من DE على عملية الأنقسام الميتوزي وحبوب اللقاح وبعض العمليات البيوكيميائية داخل

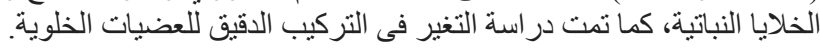

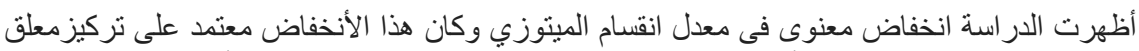

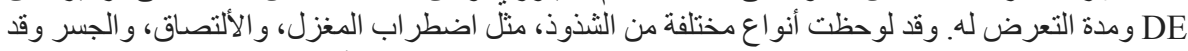

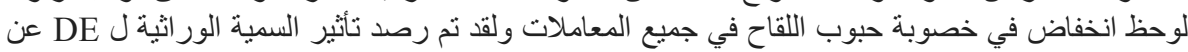

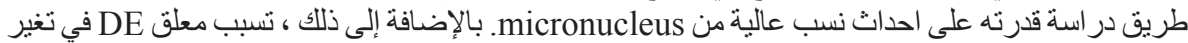

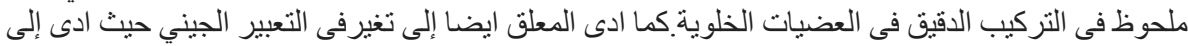

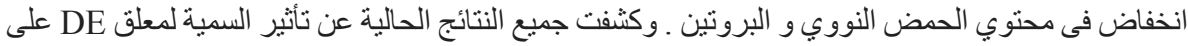

